\title{
Penyakit Periodontal pada Masa Kehamilan dan Perawatannya
}

\author{
Gabriela C. Slat, ${ }^{1}$ Johanna A. Khoman, ${ }^{1}$ Janno B. B. Bernadus ${ }^{2}$
}

\author{
${ }^{1}$ Program Studi Pendidikan Dokter Gigi Fakultas Kedokteran Universitas Sam Ratulangi. \\ Manado, Indonesia \\ ${ }^{2}$ Bagian Parasitologi Fakultas Kedokteran Universitas Sam Ratulangi, Manado, Indonesia \\ Email: gabrielacornellia@gmail.com
}

\begin{abstract}
Hormonal changes occur during pregnancy and affect the response of periodontal tissue to local factors, therefore, the risk of periodontal disease increases. Dentists have to know the treatment options that can be given to pregnant patients with periodontal disease especially the current treatments. This study was aimed to summarize the triggering factors that could worsen and the current treatment of periodontal disease during pregnancy. This was a literature review study using databases of Google scholar, Pubmed, and Science direct. After selection, there were 10 literatures; seven literatures discussed about the worsening factors of periodontal disease during pregnancy and three literatures discussed about the current treatment. The results showed several factors that could worsen periodontal disease during pregnancy, as follows: plaque, gestational age, caries, maternal age, education level, knowledge, oral hygiene behavior, treatment costs, frequency and time of tooth brushing, socio-economic status, occupation, irregular arrangement of teeth, and tobacco use. Current treatments of periodontal disease during pregnancy included the consumption of Lactobacillus reuteri-containing lozenges for pregnancy gingivitis, a water-cooled Nd: YAG (neodymium-doped yttrium aluminum garnet) pulsed laser, and transarterial embolisation for pregnancy pyogenic granuloma. In conclusion, periodontal treatment can improve periodontal status, therefore, pregnant woman with periodontal disease need to be treated.
\end{abstract}

Keywords: pregnancy; periodontal disease; worsening factors; recent treatment

\begin{abstract}
Abstrak: Selama kehamilan terjadi perubahan hormonal yang memengaruhi respons jaringan periodontal terhadap faktor lokal sehingga risiko terjadinya penyakit periodontal semakin besar. Dokter gigi perlu mengetahui pilihan perawatan yang dapat diberikan kepada pasien hamil dengan penyakit periodontal khususnya perawatan terkini. Penelitian ini bertujuan untuk merangkum faktor-faktor yang dapat memperburuk dan perawatan terkini penyakit periodontal pada masa kehamilan. Jenis penelitian ini ialah suatu literature review menggunakan tiga database yaitu Google cendekia, Pubmed dan Science direct. Setelah melalui tahapan seleksi studi, didapatkan 10 literatur; tujuh literatur mengenai faktor-faktor yang dapat memperburuk penyakit periodontal pada masa kehamilan dan tiga literatur lainnya membahas perawatan terkini. Hasil penelitian mendapatkan bahwa terdapat beberapa faktor yang dapat memperburuk penyakit periodontal pada masa kehamilan yakni: plak, usia kehamilan, karies, usia ibu hamil, tingkat pendidikan, pengetahuan, perilaku kebersihan gigi dan mulut, biaya perawatan, frekuensi dan waktu menyikat gigi, status sosial-ekonomi, pekerjaan, susunan gigi yang tidak beraturan, dan penggunaan tembakau. Perawatan terkini penyakit periodontal pada masa kehamilan dapat berupa konsumsi tablet hisap yang mengandung Lactobacillus reuteri untuk gingivitis kehamilan, laser berdenyut Nd: YAG (neodymium-doped yttrium aluminium garnet) berpendingin air, dan embolisasi transarterial untuk granuloma piogenik kehamilan. Simpulan penelitian ini ialah perawatan periodontal dapat memperbaiki status periodontal sehingga wanita hamil dengan penyakit periodontal perlu menerima perawatan.
\end{abstract}

Kata kunci: penyakit periodontal; kehamilan; faktor yang memperburuk; perawatan terkini 


\section{PENDAHULUAN}

Kehamilan merupakan fase penting selama periode reproduksi siklus hidup wanita di mana terjadi serangkaian perubahan hormonal yang menyebabkan tubuh wanita mengalami berbagai perubahan fisik dan fisiologik, termasuk masalah mulut yang berhubungan dengan periodonsium. Selama kehamilan hormon progesteron dan estrogen secara terus menerus disekresikan oleh korpus luteum sehingga menyebabkan terjadinya peningkatan kadar hormon dalam sirkulasi darah dan memengaruhi respons jaringan periodontal terhadap faktor lokal sehingga risiko terjadinya penyakit periodontal semakin besar. ${ }^{1,2}$

Penyakit periodontal menjadi penyakit yang ditemukan di seluruh dunia dan menyerang hingga $90 \%$ populasi termasuk ibu hamil, baik sebagai gingivitis yang merupakan tahap awal dari penyakit periodontal atau periodontitis yakni bentuk paling serius dari penyakit periodontal., Hasil penelitian Bansal menunjukkan prevalensi gingivitis kehamilan (pregnancy gingivitis) berkisar 30\%-100\% dari total ibu hamil di dunia. ${ }^{5}$ Hasil RISKESDAS pada tahun 2018 menyebutkan bahwa wanita di Indonesia memiliki prevalensi gingivitis sebesar $74 \% .^{6}$

Penyakit periodontal memungkinkan adanya hasil kehamilan yang merugikan seperti prematuritas, bayi berat lahir rendah, preeklamsia, dan keguguran. ${ }^{7}$ Ardakani et al pada penelitiannya mendapatkan bahwa penyakit periodontal selama masa kehamilan menjadi faktor risiko kejadian bayi berat lahir rendah. Namun, penelitian Vett Ore et al mengatakan meskipun berbagai penelitian melaporkan adanya hubungan positif antara penyakit periodontal dengan hasil kehamilan yang merugikan, tetapi sedikit yang meneliti mengenai faktor lain terkait kehamilan yang dapat memperburuk penyakit periodontal karena terdapat kemungkinan adanya faktor lain di luar kondisi kesehatan gigi mulut ibu hamil yang dapat berpengaruh juga. ${ }^{8}$

Perawatan periodontal dapat menghasilkan perbaikan yang bermakna dalam status periodontal serta penurunan tingkat mikro- organisme dan mediator inflamasi, sehingga pasien hamil dengan penyakit periodontal perlu menerima perawatan dan juga diberi tahu bahwa mereka berisiko tinggi terkena penyakit periodontal. ${ }^{1}$ Beberapa perawatan terkini telah dicoba untuk menangani penyakit periodontal pada masa kehamilan seperti penelitian Schlagenhauf et $\mathrm{al}^{9}$ yang mengatakan bahwa konsumsi tablet hisap yang mengandung Lactobacillus reuteri dapat berguna dalam pengendalian gingivitis kehamilan. Oleh karena itu, para dokter gigi perlu mengetahui pilihan perawatan apa saja yang dapat diberikan kepada pasien hamil dengan penyakit periodontal, terlebih metode perawatan terkini yang ternyata efektif dalam merawat penyakit periodontal pada masa kehamilan. ${ }^{10}$

Berdasarkan latar belakang yang telah dipaparkan, penulis tertarik untuk melakukan penelitian dalam bentuk literature review mengenai faktor-faktor yang dapat memperburuk dan perawatan terkini penyakit periodontal pada masa kehamilan.

\section{METODE PENELITIAN}

Penelitian ini merupakan suatu penelitian kualitatif berbentuk literature review. Pencarian literatur dilakukan dengan mengumpulkan data dari berbagai database yakni: Google Cendekia, Pubmed, dan Science Direct. Pencarian literatur memakai kata kunci dan boolean operator. Kriteria inklusi dan eksklusi dalam penelitian ini ditentukan memakai strategi PICOS framework dengan kriteria inklusi yakni: artikel bereputasi nasional maupun internasional di mana pasien hamil dengan penyakit periodontal merupakan populasi penelitian, membahas tentang faktor-faktor yang memperburuk dan perawatan terkini penyakit periodontal pada masa kehamilan, tahun publikasi 2011-2021, serta berbahasa Inggris dan bahasa Indonesia.

\section{HASIL PENELITIAN}

Setelah melalui tahapan seleksi studi, penulis mendapatkan 10 literatur bereputasi nasional maupun internasional dari tiga database (Google cendekia, Pubmed dan Science direct) yakni: tujuh literatur 
membahas mengenai faktor-faktor yang dapat memperburuk penyakit periodontal pada masa kehamilan dan tiga literatur lainnya membahas tentang perawatan terkini penyakit periodontal pada masa kehamilan.

Tabel 1 memperlihatkan karakteristik dari masing-masing literatur mengenai faktor-faktor yang dapat memperburuk penyakit periodontal pada masa kehamilan dengan jumlah sampel paling banyak yakni 1452 ibu hamil pada penelitian Erchick et $\mathrm{al}^{11}$ di Nepal tahun 2019 dan jumlah sampel paling sedikit yakni 60 ibu hamil pada penelitian Hartati et al ${ }^{12}$ di Talang Tegal tahun 2011. Empat dari tujuh literatur berlokasi di Indonesia sedangkan tiga lainnya di luar negeri.

Tabel 2 memperlihatkan karakteristik dari masing-masing literatur mengenai perawatan terkini penyakit periodontal pada masa kehamilan dengan jumlah sampel terbanyak yakni 45 ibu hamil dalam penelitian randomized controlled trial (RCT) dari Schlagenhauf et $\mathrm{al}^{9}$ pada tahun 2016 di Jerman dan dapat dilihat bahwa semua literatur berlokasi di luar negeri.

Tabel 3 memperlihatkan distribusi hasil penelitian dari tujuh literatur mengenai faktor-faktor yang dapat memperburuk penyakit periodontal pada masa kehamilan. Terdapat 13 faktor yang dapat memperburuk penyakit periodontal pada masa kehamilan dan usia kehamilan menjadi faktor yang paling sering muncul yakni ditemukan pada lima dari tujuh literatur.

Tabel 4 memperlihatkan distribusi hasil penelitian dari tiga literatur mengenai perawatan terkini penyakit periodontal pada masa kehamilan.

\section{BAHASAN}

Penelitian ini mendapatkan beberapa faktor yang dapat memperburuk kejadian penyakit periodontal pada masa kehamilan. Penelitian Hartati et al ${ }^{12}$ di Talang Tegal dan Umniyati et al $^{5}$ di Kelapa Gading Jakarta Utara melaporkan bahwa, kejadian gingivitis kehamilan berkaitan erat dengan adanya plak, bahkan merupakan faktor yang paling dominan berhubungan dengan kejadian gingivitis pada ibu hamil. Hal ini didukung oleh Newman et $\mathrm{al}^{19}$ yang menyatakan bahwa

Tabel 1. Karakteristik literatur mengenai faktor-faktor yang dapat memperburuk penyakit periodontal pada masa kehamilan

\begin{tabular}{llcccc}
\hline \multicolumn{1}{c}{ Peneliti } & $\begin{array}{c}\text { Desain } \\
\text { Penelitian }\end{array}$ & Lokasi & Tahun & Sampel & Populasi \\
\hline Hartati et al $^{12}$ & Cross-sectional & $\begin{array}{c}\text { Talang Tegal, } \\
\text { Indonesia }\end{array}$ & 2011 & 60 & 195 \\
Nataris dan Santik $^{13}$ & Cross-sectional & $\begin{array}{c}\text { Brebes, Indonesia } \\
\text { Kelapa Gading, }\end{array}$ & 2017 & 71 & 206 \\
Umniyati et al $^{5}$ & Cross-sectional & $\begin{array}{c}\text { Indonesia } \\
\text { Brazil }\end{array}$ & 2012 & 334 & 334 \\
Vogt et al $^{14}$ & Cross-sectional & Nepal & 2019 & 1452 & 1452 \\
Erchick et al $^{11}$ & Cross-sectional & Rwanda, Afrika & 2021 & 400 & 400 \\
Uwambaye et al $^{15}$ & Cross-sectional \\
Pradnyanaputri et al & Cross-sectional & $\begin{array}{c}\text { Klungkung, } \\
\text { Indonesia }\end{array}$ & 2017 & 85 & 85 \\
& & & & & \\
\hline
\end{tabular}

Tabel 2. Karakteristik literatur mengenai perawatan terkini penyakit periodontal pada masa kehamilan

\begin{tabular}{lccccc}
\hline \multicolumn{1}{c}{ Peneliti } & Desain Penelitian & Lokasi & Tahun & Sampel & Populasi \\
\hline${\text { Schlagenhauf et } \mathrm{al}^{9}}^{9}$ & Randomized controlled trial & Jerman & 2016 & 24 & 61 \\
Tsai et al $^{17}$ & Case report & Taipei & 2015 & 1 & 1 \\
Zeng et al $^{18}$ & Case report & China & 2020 & 1 & 1 \\
\hline
\end{tabular}


Tabel 3. Distribusi hasil penelitian literatur mengenai faktor-faktor yang dapat memperburuk penyakit periodontal pada masa kehamilan

\begin{tabular}{clcc}
\hline No & \multicolumn{1}{c}{ Hasil } & Jumlah & Nomor literatur \\
\hline 1. & Plak & 2 literatur & 5 dan 12 \\
2. & Karies & 2 literatur & 12 dan 13 \\
3. & Usia kehamilan (trimester) & 5 literatur & $5,13,14,15$, dan 16 \\
4. & Usia Ibu & 3 literatur & 11,14 , dan 15 \\
5. & Tingkat pendidikan & 3 literatur & 13,15 , dan 16 \\
6. & Pekerjaan & 2 literatur & 15 dan 16 \\
7. & Susunan gigi yang tidak beraturan & 1 literatur & 13 \\
8. & Pengetahuan & 1 literatur & 13 \\
9. & Perilaku kebersihan gigi dan mulut & 1 literatur & 13 \\
10. & Frekuensi dan waktu menyikat gigi & 1 literatur & 5 \\
11. & Biaya perawatan & 1 literatur & 11 \\
12. & Status sosial ekonomi & 1 literatur & 15 \\
13. & Penggunaan tembakau & 1 literatur & 15 \\
\hline
\end{tabular}

Tabel 4. Distribusi hasil penelitian dari literatur-literatur mengenai perawatan terkini penyakit periodontal pada masa kehamilan

\begin{tabular}{lcc}
\hline Hasil & Jumlah & $\begin{array}{c}\text { Nomor } \\
\text { literatur }\end{array}$ \\
\hline $\begin{array}{l}\text { Awalnya rata-rata indeks gingiva dan indeks plak tidak berbeda secara } \\
\text { bermakna antara kedua kelompok. Rerata kadar serum TNF- } \alpha \text { pada }\end{array}$ & & 9 \\
kelompok uji secara bermakna $(\mathrm{p}<0,02)$ lebih rendah dibanding kelompok & & \\
plasebo. Saat evaluasi ulang, rerata indeks gingiva dan indeks plak dari & \\
kelompok uji secara bermakna (p<0,0001) lebih rendah daripada kelompok & \\
placebo sedangkan rerata kadar serum TNF- $\alpha$ tidak lagi berbeda secara & & \\
bermakna antar kelompok. & \\
Lesi menyusut dengan cepat setelah embolisasi transarterial, hampir & 1 literatur \\
menghilang setelah 1 bulan, dan tidak diperlukan eksisi bedah lebih lanjut. & \\
Tidak ada kekambuhan atau komplikasi yang diamati setelah dilakukan & \\
follow up pasien selama 1 tahun. & \\
$\begin{array}{l}\text { Dua granuloma piogenik kehamilan raksasa dari pasien dengan aman, } \\
\text { lengkap dan minimal invasif dihilangkan dengan menggunakan laser }\end{array}$ & \\
berdenyut Nd: YAG (neodymium-doped yttrium aluminium garnet) \\
berpendingin air tanpa agen anestesi, penjahitan atau antibiotik. Pasien \\
berhasil melahirkan bayinya melalui persalinan normal pada usia kehamilan \\
$\begin{array}{l}\text { 40 minggu, area yang dilakukan perawatan sembuh dengan baik, tidak ada } \\
\text { kekambuhan yang diamati } 1 \text { tahun setelah perawatan dan celah yang } \\
\text { disebabkan oleh granuloma piogenik tertutup secara spontan. }\end{array}$ \\
\hline
\end{tabular}

mikroorganisme yang berkoloni pada gigi yaitu plak bakteri dan produk-produk yang dihasilkannya merupakan penyebab utama terjadinya penyakit periodontal serta selaras dengan penelitian yang sudah dilakukan Loe tahun 1995 yang telah membuktikan bahwa akumulasi plak menjadi penyebab utama penyakit periodontal pada masa kehamilan. ${ }^{19}$

Sekitar $10^{11}$ bakteri terkandung pada 1 gr plak. Jumlah bakteri plak pada satu permukaan gigi dapat melebihi $10^{9}$ sel, sedangkan dalam poket periodontal dapat berkisar dari $10^{3}$ hingga lebih dari $10^{8}$ 
bakteri pada poket yang dalam. Akumulasi bakteri plak pada permukaan gigi maupun di dalam servik gingiva dapat memicu munculnya reaksi peradangan akibat produk toksik yang dihasilkan mikroorganisme plak. ${ }^{19}$

Hasil penelitian lima dari tujuh literatur $^{5,12-14,16}$ mendapatkan bahwa usia kehamilan berhubungan dengan kejadian gingivitis kehamilan, dan tiga dari lima literatur tersebut menyatakan bahwa tingkat gingivitis kehamilan lebih tinggi pada trimester ketiga. Hal tersebut sejalan dengan temuan dari Maybodi et $\mathrm{al}^{20}$ yang mendapatkan adanya hubungan bermakna antara usia kehamilan dengan gingivitis. Tingkat keparahan gingivitis meningkat karena terjadi peningkatan sintesis prostaglandin E2 $\left(\mathrm{PGE}_{2}\right)$ di cairan sulkus gingiva dan permeabilitas vaskular serta menurunnya kemotaksis dan fagositosis polimorfonuklear yang menekan respons kekebalan jaringan periodontal terhadap plak sebagai reaksi atas tingginya kadar hormon progesteron dan estrogen seiring dengan meningkatnya usia kehamilan.

Hartati et $\mathrm{al}^{12}$ pada penelitiannya terhadap 60 ibu hamil di Talang Tegal mendapat hasil yang serupa dengan penelitian Nataris dan Santik $^{13}$ pada 71 ibu hamil di Brebes yakni adanya hubungan bermakna antara faktor karies dengan gingivitis kehamilan yaitu karies yang tidak ditangani dengan tepat akan memberi dampak pada gigi dan menyebar pada jaringan periodontal yang akhirnya menghasilkan peradangan seperti gingivitis. Risiko karies lebih mudah terjadi pada ibu hamil dikarenakan pada masa kehamilan seorang ibu sering mengalami muntah yang bercampur dengan asam lambung dan ketika tidak dilakukan tindakan kebersihan mulut yang tepat setelah muntah seperti kumur-kumur atau menyikat gigi, maka sisa muntahan tersebut menempel pada gigi dan lambat laun akan menyebabkan kerusakan. ${ }^{21}$

Salah satu faktor yang dapat memperburuk penyakit periodontal pada masa kehamilan yang ditemui dalam penelitian Vogt et al ${ }^{14}$ di Brazil, penelitian Erchick et a ${ }^{11}$ di Nepal, dan penelitian Uwambaye et $\mathrm{al}^{15}$ di Rwanda yaitu usia ibu hamil. Wanita yang lebih muda memiliki kemungkinan lebih kecil untuk mengalami periodontitis dibandingkan dengan wanita yang lebih tua karena tingkat kehilangan perlekatan yang tinggi akibat penuaan. Reynolds ${ }^{22}$ mengatakan juga bahwa peningkatan kerentanan terhadap periodontitis seiring bertambahnya usia dapat disebabkan oleh paparan terus menerus terhadap kondisi inflamasi, serta perubahan kapasitas penyembuhan dan sel akibat penuaan.

Hasil penelitian dari Nataris dan Santik. ${ }^{13}$ di Brebes yang didukung oleh hasil penelitian Pradnyanaputri ${ }^{16}$ di Klungkung menyatakan bahwa jumlah gingivitis pada ibu hamil semakin meningkat berkorelasi dengan tingkat pendidikan. Temuan yang sama juga dilaporkan pada penelitian Uwambaye et $\mathrm{a}^{15}$ di Rwanda yang mengatakan tingkat pendidikan secara bermakna berhubungan dengan periodontitis. Ibu hamil dengan tingkat pendidikan rendah memiliki peluang lebih besar untuk mengalami gingivitis dan periodontitis karena kurangnya pendidikan dapat berarti juga kurangnya pengetahuan ibu hamil tentang praktik kebersihan gigi mulut, perilaku kebersihan gigi dan mulut yang tepat seperti frekuensi serta waktu menyikat gigi yang terbukti berhubungan berdasarkan hasil penelitian Umniyati ${ }^{5}$ di Jakarta Utara.

Gingivitis meningkat sebesar 3\% di antara wanita hamil yang melaporkan bahwa biaya perawatan menjadi penghalang untuk mencari perawatan gigi. Hal ini merupakan salah satu faktor yang memperberat penyakit periodontal yang dilaporkan oleh Erchick et al ${ }^{11}$ di pedesaan Nepal. Biaya perawatan yang mahal menyebabkan keengganan ibu hamil untuk berkunjung ke dokter gigi, dan hal ini berkaitan juga dengan status sosial ekonomi serta pekerjaan ibu hamil. Hal ini didukung oleh hasil penelitian Pradnyanaputri et al ${ }^{16}$ di Klungkung yakni ibu hamil yang tidak bekerja lebih banyak mengalami gingivitis (42\%) dibandingkan ibu hamil yang bekerja $(37,1 \%)$ dan hasil penelitian Uwambaye et $\mathrm{al}^{15}$ di Rwanda yang menunjukkan status sosial ekonomi dan pekerjaan ibu hamil secara bermakna berhubungan dengan peri- 
odontitis dikarenakan ketidakmampuan untuk menjaga kebersihan gigi lewat pembelian sikat dan pasta gigi sehingga rentan terhadap kebersihan mulut yang buruk serta ketidakmampuan membayar perawatan gigi.

Hasil penelitian 1 dari 7 literatur yakni penelitian Nataris dan Santik ${ }^{13}$ pada 71 ibu hamil di Brebes mendapatkan salah satu faktor yang dapat memperberat terjadinya gingivitis kehamilan yakni susunan gigi yang tidak beraturan $(p=0,034)$. Susunan gigi berjejal pada ibu hamil meningkatkan 1,3 kali risiko gingivitis dibanding ibu hamil tanpa masalah susunan gigi. Hal ini sejalan dengan Cameron dan Widmer yang menyatakan bahwa susunan gigi yang tak beraturan seperti berjejal atau bertumpuk dapat menyusahkan pembersihan plak (sebagai faktor utama terjadinya gingivitis) karena sisa makanan sehingga risiko terjadinya gingivitis semakin tinggi. ${ }^{13}$ Namun hal ini tidak sesuai dengan hasil penelitian Hartati et al $^{12}$ pada 60 ibu hamil di Talang Tegal yakni tidak terdapat hubungan bermakna antara faktor susunan gigi yang tidak teratur dengan gingivitis pada ibu hamil $(p=0,73)$ karena hanya enam ibu hamil dengan gigi tak beraturan yang mengalami gingivitis dari total 60 sampel dan terdapat dua ibu hamil dengan gigi tidak beraturan yang tidak mengalami gingivitis.

Seorang wanita hamil yang pernah menggunakan tembakau memiliki risiko enam kali lebih tinggi terkena periodontitis dibandingkan dengan yang tidak pernah menggunakan produk tembakau. Hal ini selaras dengan penelitian Uwambaye et $\mathrm{al}^{15}$ pada 400 ibu hamil di Rwanda yang menyatakan bahwa penggunaan tembakau $\mathrm{OR}=6,89(95 \%$ CI. 1,78-60,65) secara bermakna berhubungan dengan periodontitis. Didukung oleh penelitian sebelumnya oleh Piscoya et $\mathrm{al}^{23}$ di Brasil yang sepakat bahwa merokok menjadi faktor yang berkaitan dengan periodontitis pada ibu hamil. Zat-zat toksik yang terkandung dalam rokok seperti nikotin dapat merusak perlekatan dan pertumbuhan sel fibroblas ligamen periodontal, menurunkan jumlah protein fibroblas, serta memicu kerusakan sel membran sehingga risiko periodontitis semakin tinggi.

Schlagenhauf et $\mathrm{al}^{9}$ melakukan penelitian pada 45 wanita hamil trimester ketiga di Jerman mengenai perawatan gingivitis kehamilan menggunakan tablet hisap mengandung Lactobacillus reuteri. Indeks gingiva dan indeks plak dinilai serta darah vena diambil untuk analisis TNF- $\alpha$. Sampel dibagi menjadi dua kelompok (24 uji, 21 plasebo) dan secara acak diberikan tablet hisap untuk dikonsumsi dua kali sehari sampai melahirkan yang mengandung $\geq 10^{8}$ unit pembentuk koloni $L$. reuteri ATCC PTA 5289 dan $\geq 10^{8}$ unit pembentuk koloni L. reuteri DSM 17938 (kelompok uji) dan tidak mengandung strain L. reuteri (kelompok plasebo). Hasil penelitian dengan jelas menunjukkan hubungan bermakna antara konsumsi rutin tablet hisap yang mengandung $L$. reuteri dengan pengurangan peradangan gingiva dan cakupan plak pada wanita hamil yang sehat. Hal ini sejalan dengan temuan klinis sebelumnya oleh Twetman et al pada tahun 2009 yang melaporkan pengaruh bermakna yang menguntungkan dari permen karet mengandung $L$. reuteri pada manifestasi perdarahan saat probing pasien dewasa muda yang menderita gingivitis kronis. ${ }^{9}$

Penatalaksanaan granuloma piogenik umumnya tergantung pada berat ringannya gejala dan kondisi pasien, terutama pada ibu hamil. Jika lesi kecil, tidak nyeri dan bebas perdarahan, hanya perawatan suportif, observasi ketat dan tindak lanjut yang disarankan. Di sisi lain, eksisi bedah dengan menghilangkan iritan (kalkulus, plak dan sumber trauma) secara tradisional merupakan pilihan pengobatan pertama. Namun, dalam beberapa kasus, lesi mungkin sangat besar atau di daerah yang sulit dibedah. Memilih alternatif yang tepat sangatlah penting terutama bagi ibu hamil. ${ }^{17}$

Laporan kasus dari Tsai et $\mathrm{al}^{17}$ yang menangani granuloma piogenik kehamilan dengan perdarahan masif yang mengancam jiwa pada seorang wanita berusia 33 tahun (usia kehamilan 34 minggu) di Taipei tahun 2015. Pasien dibawa ke ruang gawat darurat dengan perdarahan mulut yang parah setelah menyikat gigi di pagi hari. Syok hipo- 
volemik dikendalikan dan kesadaran pulih setelah resusitasi cairan dan transfusi darah. Awalnya eksisi bedah merupakan rencana perawatan untuk kasus ini dan embolisasi transarterial dilakukan sebelum eksisi bedah karena ukuran granuloma piogenik yang relatif besar dan kecenderungan perdarahan yang mudah. Setelah kateterisasi superselektif ke dalam arteri lingual, campuran $20 \%$ n-butyl cyanoacrylate disiapkan dengan $0,5 \mathrm{ml}$-butyl cyanoacrylate (Ingenor, Gennevilliers, France) dan 2,0 ml minyak etiodisasi (Lipiodol Ultra Fluid; Guerbet, Aulnay-sous-Bois, France) diinfuskan untuk embolisasi.

Penghapusan total noda tumor serta pseudoaneurisma dikonfirmasi oleh angiografi segera setelah embolisasi. Eksisi bedah lebih lanjut tidak diperlukan setelah embolisasi karena penyusutan lesi jelas dalam waktu yang singkat dan lesi hilang setelah satu bulan. Pasien terbebas dari nyeri luka, risiko infeksi dan rasa tidak nyaman saat makan. Menurut Tsai et al ${ }^{17}$ masih sedikit artikel yang membahas tentang embolisasi untuk mengobati granuloma piogenik hemoragik yang sangat besar terkhususnya pada wanita hamil.

Penatalaksanaan lain granuloma piogenik kehamilan dilakukan oleh Zeng et al ${ }^{18}$ pada seorang wanita berusia 26 tahun dengan usia kehamilan 34 minggu di China tahun 2020 dengan menggunakan laser berdenyut Nd: YAG (neodymium-doped yttrium aluminium garnet) berpendingin air tanpa agen anestesi, penjahitan atau antibiotik. Ukurannya yang besar dan perdarahan hebat saat menyikat gigi dan makan menyebabkan asupan nutrisi harian pasien sangat terpengaruh. Eksisi dilakukan dengan daya $3 \mathrm{~W}$, air 8 , gas 8 , serat laser digerakkan maju mundur di sepanjang area bertangkai selama 15 detik. Dibandingkan dengan eksisi pisau bedah tradisional, terapi laser mencapai presisi dan hasil estetika yang lebih baik melalui serat fleksibel, koagulasi langsung, dan penglihatan yang jelas.

Eksisi bedah dengan bantuan laser $\mathrm{CO}_{2}$ dalam terapi granuloma piogenik kehamilan telah dilaporkan sebelumnya dalam pene- litian Lindenmüller et al pada tahun 2010, tetapi laser berdenyut Nd: YAG berpendingin air seperti yang digunakan oleh Zeng et $\mathrm{al}^{18}$ lebih disukai karena keuntungannya yakni kerusakan panas yang lebih sedikit, homeostasis yang lebih baik, efek antibakteri, penetrasi jaringan yang lebih dalam, dan diserap dengan baik oleh pigmen. Ciriciri ini cocok untuk pengobatan granuloma piogenik kehamilan dengan tujuan mencegah perdarahan masif dan kemungkinan infeksi sekunder. ${ }^{18}$ Penggunaan laser ini masih jarang ditemui terlebih khusus dalam perawatan penyakit periodontal pada ibu hamil. Hal tersebut kemungkinan karena kurangnya publikasi sehingga orang masih kurang mengetahui tentang laser ini baik dalam hal kegunaan, indikasi, kelebihan, kekurangan, harga, dan prosedur penggunaannya.

Perawatan-perawatan terkini yang telah dipaparkan dapat saja diterapkan di Indonesia tetapi perlu diingat bahwa membawa masuk suatu perawatan atau pengobatan yang baru dari negara lain ke dalam suatu negara harus melalui proses perizinan dan pengujian sebelum dipakai.

Keterbatasan penelitian ini ialah karena data penelitian merupakan data sekunder sehingga: tidak dapat dilakukan intervensi terhadap hasil penelitian yang ditemukan; lokasi penelitian yang beragam dari literatur yang digunakan sehingga populasi sulit digeneralisasi; masih sedikit literatur mengenai perawatan terkini penyakit periodontal pada masa kehamilan sehingga terbatas dalam memberi informasi mengenai tingkat keberhasilan perawatan untuk setiap jenis penyakit periodontal; belum ada data pembanding dari penelitian lain yang sejenis dan informasi mengenai kelebihan kekurangan opsi perawatan tersebut apabila digunakan pada setiap trimester kehamilan.

\section{SIMPULAN}

Faktor-faktor yang dapat memperburuk penyakit periodontal pada masa kehamilan yakni: plak, usia kehamilan, karies, usia ibu hamil, tingkat pendidikan, pengetahuan, perilaku kebersihan gigi dan mulut, biaya perawatan, frekuensi dan waktu menyikat 
gigi, status sosial-ekonomi, pekerjaan, susunan gigi yang tidak beraturan, dan penggunaan tembakau. Perawatan terkini penyakit periodontal dapat berupa konsumsi tablet hisap yang mengandung Lactobacillus reuteri untuk gingivitis kehamilan, serta laser berdenyut Nd: YAG (neodymiumdoped yttrium aluminium garnet) berpendingin air dan embolisasi transarterial untuk granuloma piogenik kehamilan.

Perawatan periodontal dapat memperbaiki status periodontal sehingga pasien hamil dengan penyakit periodontal perlu menerima perawatan.

\section{Konflik Kepentingan}

Penulis menyatakan tidak terdapat konflik kepentingan dalam studi ini.

\section{DAFTAR PUSTAKA}

1. Bathla S. Textbook of Periodontics (1st ed). India: Jaypee Brothers Medical Publishers; 2017.

2. Haryani W, Winta N, Purwati DE. Correlation of pregnancy stage and gingiva status of pregnant woman who visited Rsud Lebong-Bengkulu. Int J Sci Res Educ. 2018;6(7):7986-93.

3. Salih Y, Nasr AM, Ahmed ABA, Sharif ME, Adam I. Prevalence of and risk factors for periodontal disease among pregnant women in an antenatal care clinic in Khartoum, Sudan. BMC Res Notes [Internet]. 2020;13(147):1-5. Available from: https://doi.org/10.1186/s13104020-04998-3

4. Hartnett E, Haber J, Krainovich-Miller B, Bella A, Vasilyeva A, Lange Kessler J. Oral health in pregnancy. JOGNN - J Obstet Gynecol Neonatal Nurs [Internet]. 2016;45(4):565-73. Available from: http://dx.doi.org/10.1016/j.jogn.2016.0 4.005

5. Umniyati H, Amanah SP, Maulani C. Hubungan gingivitis dengan faktorfaktor risiko pada ibu hamil. Padjadjaran J Dent Res Student. 2020;4(1):36-42.

6. Kementerian Kesehatan RI. Laporan nasional riskesdas 2018 [Internet]. Jakarta: Lembaga Penerbit Badan Penelitian dan Pengembangan Kesehatan (LPB); 2019. Available from: http://www.yankes. kemkes.go.id/assets/downloads/PMK
No. 57 Tahun 2013 tentang PTRM.pdf

7. Lachat MF, Solnik AL, Nana AD, Citron TL. Periodontal disease in pregnancy: review of the evidence and prevention strategies. J Perinat Neonatal Nurs. 2011;25(4):312-9.

8. Soulissa AG. Hubungan kehamilan dan penyakit periodontal. Jurnal PDGI. 2014;63(3):71-7.

9. Schlagenhauf U, Jakob L, Eigenthaler M, Segerer S, Jockel-Schneider Y, Rehn M. Regular consumption of Lactobacillus reuteri-containing lozenges reduces pregnancy gingivitis: an rct. J Clin Periodontol. 2016;43(11):948-54.

10. Perry DA, Beemsterboer PL, Essex G. Periodontology for the dental hygienist (4th ed). Canada: Elsevier Inc; 2014.

11. Erchick DJ, Rai B, Agrawal NK, Khatry SK, Katz J, LeClerq SC, et al. Oral hygiene, prevalence of gingivitis, and associated risk factors among pregnant women in Sarlahi District, Nepal. BMC Oral Health. 2019;19(1):1-11.

12. Hartati, Rusmini, Waluyo BT. Analisis faktorfaktor yang berhubungan dengan kejadian gingivitis pada ibu hamil di wilayah kerja Puskesmas Talang Tegal. J Ilm Kesehat Keperawatan. 2011;7(3): 170-89.

13. Nataris AS, Santik YDP. Faktor kejadian gingivitis pada ibu hamil. Higeia $\mathbf{J}$ Public Heal Res Dev. 2017;1(3):117-28.

14. Vogt M, Sallum AW, Cecatti JG, Morais SS. Factors associated with the prevalence of periodontal disease in low-risk pregnant women. Reprod Health. 2012;9(1):1-8.

15. Uwambaye P, Kerr M, Rulisa S, Harlan S, Munyanshongore C. Prevalence of periodontitis and associated factors among pregnant women: a cross sectional survey in Southern Province, Rwanda. Rwanda J Med Heal Sci. 2021;4(1):131-50.

16. Pradnyanaputri KE, Kusumadewi S, Susanti DNA. Prevalensi gingivitis pada ibu hamil berdasarkan usia kehamilan, pekerjaan, dan pendidikan di RSUD Klungkung tahun 2017. ODONTO Dent J. 2018;5:97-101.

17. Tsai KY, Wang WH, Chang GH, Tsai YH. Treatment of pregnancy-associated oral pyogenic granuloma with life-threatening haemorrhage by transarterial 
embolisation. J Laryngol Otol. 2015; 129(6):607-10.

18. Zeng H, Yang R, Ding Y. Use of a watercooled Nd: YAG pulsed laser in the treatment of giant gingival pyogenic granulomas during pregnancy. J Stomatol Oral Maxillofac Surg [Internet]. 2020;121(3):305-7. Available from: https://doi.org/10.1016/j.jormas. 2019.05.006

19. Newman MG, Takei HH, Klokkevold PR, Carranza FA. Newman and Carranza's clinical periodontology (13th ed). Philadelphia: Elsevier Inc; 2019.

20. Maybodi FR, Haerian-Ardakani A, Vaziri F, Khabbazian A, Mohammadi-Asl S.
CPITN changes during pregnancy and maternal demographic factors impact on periodontal health. Iran J Reprod Med. 2015;13(2):107-12.

21. Obi AL. Indeks DMF-T dan OHIS pada ibu hamil. Dent Ther J. 2019;1(1):12-22.

22. Reynolds MA. Modifiable risk factors in periodontitis: at the intersection of aging and disease. Periodontol 2000. 2013; 64(1):7-19.

23. Piscoya MDB de V, Ximenes RA de A, Moura da Silva G, Jamelli SR, Coutinho SB. Periodontitis-associated risk factors in pregnant women. Clin Sci. 2012;67(1): 27-33. 